\title{
Antioxidant effect of Arabic gum against mercuric chloride-induced nephrotoxicity
}

\author{
This article was published in the following Dove Press journal: \\ Drug Design, Development and Therapy \\ 18 October 2013 \\ Number of times this article has been viewed
}

\author{
Ali M Gado' \\ Badr A Aldahmash ${ }^{2}$ \\ 'Forensic Medicine and Clinical \\ Toxicology Department, College \\ of Medicine, Tanta University, \\ Tanta, Egypt; ${ }^{2}$ Medical Laboratory \\ Department, College of Health \\ Sciences, King Saud University, \\ Riyadh, Saudi Arabia
}

\begin{abstract}
The effects of Arabic gum (AG) against nephrotoxicity of mercury (Hg), an oxidativestress inducing substance, in rats were investigated. A single dose of mercuric chloride $(5 \mathrm{mg} / \mathrm{kg}$ intraperitoneal injection) induced renal toxicity, manifested biochemically by a significant increase in serum creatinine, blood urea nitrogen, thiobarbituric acid reactive substances, and total nitrate/nitrite production in kidney tissues. In addition, reduced glutathione, glutathione peroxidase, and catalase enzymes in renal tissues were significantly decreased. Pretreatment of rats with $\mathrm{AG}(7.5 \mathrm{~g} / \mathrm{kg} /$ day per oral administration), starting 5 days before mercuric chloride injection and continuing through the experimental period, resulted in a complete reversal of $\mathrm{Hg}$-induced increase in creatinine, blood urea nitrogen, thiobarbituric acid reactive substances, and total nitrate/nitrite to control values. Histopathologic examination of kidney tissues confirmed the biochemical data; pretreatment of AG prevented $\mathrm{Hg}$-induced degenerative changes of kidney tissues. These results indicate that AG is an efficient cytoprotective agent against $\mathrm{Hg}$-induced nephrotoxicity by a mechanism related at least in part to its ability to decrease oxidative and nitrosative stress and preserve the activity of antioxidant enzymes in kidney tissues.
\end{abstract}

Keywords: mercury, acacia gum, oxidative stress, lipid per oxidation, kidney toxicity

\section{Introduction}

Mercury $(\mathrm{Hg})$ is a hazardous environmental and industrial pollutant which induces severe alterations in the body tissues of both humans and animals. ${ }^{1,2}$ The toxicity of $\mathrm{Hg}$ depends on the form of the $\mathrm{Hg}$ compounds (elemental, inorganic, and organic). Inorganic $\mathrm{Hg}$ accumulates predominantly in the kidneys, causing acute renal failure. . $^{3,4}$ The uptake, accumulation, and toxicity of inorganic $\mathrm{Hg}$ in the kidney have been related to it binding to endogenous thiol-containing molecules. ${ }^{5}$ Thiol-containing enzymes have been recognized as the targets of inorganic $\mathrm{Hg} .{ }^{5,6}$ Moreover, binding of mercuric ions to thiol groups may cause decreased glutathione (GSH) levels, leading to increases in levels of reactive oxygen species (ROS), such as superoxide anion radicals, hydrogen peroxide, and hydroxyl radicals, which provoke lipid, protein, deoxyribonucleic acid (DNA), and ribonucleic acid (RNA) oxidation. ${ }^{7,8}$ Considering that oxidative stress and endogenous thiol depletion are involved in inorganic $\mathrm{Hg}$ toxicity, it has been suggested that antioxidants could contribute to the treatment of $\mathrm{Hg}$ poisoning. ${ }^{9,10}$ In this way, melatonin, curcumin, and vitamin $\mathrm{E}$ have been found to play a protective effect against mercuric chloride $\left(\mathrm{HgCl}_{2}\right)$-induced acute renal toxicity. ${ }^{2,11-13}$ Similarly, a number of plant extracts with antioxidant properties have been shown to inhibit $\mathrm{HgCl}_{2}$-induced renal toxicity. ${ }^{14-16}$
Correspondence: Ali M Gado Forensic Medicine and Clinical Toxicology Department, College of Medicine, Tanta University, Tanta, Egypt Email daligado@yahoo.com 
Arabic gum (AG) is a dried, gummy exudate from the stems and branches of Acacia senegal (Leguminosae), composed of calcium, magnesium, and potassium salts of the polysaccharide Arabic gum acid. ${ }^{17} \mathrm{AG}$ has been used in Arabic folk medicine to reduce both the frequency and the need for hemodialysis in chronic renal failure patients. ${ }^{18} \mathrm{AG}$ also has been shown to reduce urinary nitrogen excretion by increasing urea disposal in the cecum and lowering serum urea concentration in rats and humans. ${ }^{19,20}$ Additionally, we have recently reported that $\mathrm{AG}$ prevented gentamicin-induced nephrotoxicity. Co-treatment of AG significantly prevented gentamicin-induced lipid peroxidation in the kidney tissue, which was closely associated with protection of renal function and histological changes. ${ }^{18}$

To the best of our knowledge, there are no studies concerning the nephroprotective effect of $\mathrm{AG}$ against $\mathrm{Hg}$ intoxication. Therefore, the present study was carried out to investigate: 1) the adverse effect of acute $\mathrm{Hg}$ intoxication on the kidneys based on serum biochemical parameters, oxidative stress, and histopathologic alterations; and 2) the possible mitigating effect of $\mathrm{AG}$ against acute $\mathrm{Hg}$ intoxication in rats.

\section{Materials and methods}

\section{Chemicals}

$\mathrm{Hg}$ in the form of $\mathrm{HgCl}_{2}$ was purchased from CHEMA TEC CO (Alexandria, Egypt). AG was purchased from SigmaAldrich (St Louis, MO, USA), and thiobarbituric acid was a product of Sigma-Aldrich. All other chemicals were of the highest grade commercially available.

\section{Animals}

Male Swiss albino rats (Animal house of College of Pharmacy, King Saud University, Riyadh, Saudi Arabia) weighing 150-200 g were used in all experiments. Animals were maintained under standard conditions of temperature and humidity with regular light/dark cycles and allowed free access to food (Purina Chow, Gray Summit, MO, USA) and water. All animal experiments were conducted according to the regulations of the Committee on Bioethics for Animal Experiments of Riyadh Colleges of Dentistry and Pharmacy.

\section{Animal treatment}

The animals were divided at random into four groups of ten animals each. The first group (control) received vehicles used for $\mathrm{Hg}$ (physiological saline solution, intraperitoneal injection [IP]). The second group received AG by oral gavage $\left(7.5 \mathrm{~g} / \mathrm{kg} /\right.$ day) for 1 week. $^{21}$ The third group was injected with $\mathrm{HgCl}_{2}(5 \mathrm{mg} / \mathrm{kg} \mathrm{IP}){ }^{22}$ The fourth group, received $\mathrm{Ag}$ per oral route (os) $(7.5 \mathrm{~g} / \mathrm{kg} /$ day) for 5 days, then injected with $\mathrm{HgCl}_{2}$ (5 mg/kg IP) and continued on $\mathrm{Ag}$ daily until the end of the experiment ( 1 week). Blood samples were taken by cardiac puncture, under light ether anesthesia, into nonheparinized tubes. Serum was separated by centrifugation for 5 minutes at $1,000 \mathrm{xg}$ and stored at $-20^{\circ} \mathrm{C}$ until analysis. Animals were sacrificed by cervical dislocation and the kidneys were quickly isolated, washed with saline, blotted dry on filter paper, and weighed, and 10\% (\% weight per volume $[\mathrm{w} / \mathrm{v}])$ homogenate of the left kidney was made in ice-cold saline.

\section{Measurement of serum biochemical parameters}

Serum creatinine and blood urea nitrogen (BUN) concentrations were determined colorimetrically as described by Bonsnes and Taussky, and Hallet and Cook, respectively, using commercially available diagnostic kits (bioMérieuxRCS, Lyon, France). ${ }^{23,24}$

\section{Determination of lipid peroxides, GSH content, and enzyme activities of GSH peroxidase and catalase in kidney homogenate}

GSH content and lipid peroxidation (malondialdehyde production) in the kidney tissues were determined according to Ellman, and Ohkawa et al, respectively. ${ }^{25,26}$ The enzyme activity of glutathione peroxidase (GSH-Px) and catalase were measured in the kidney homogenates according to Kraus and Ganther, and Higgins et al, respectively. ${ }^{27,28}$

\section{Determination of total nitrate/nitrite concentrations in renal tissues}

Total nitrate/nitrite (NOx) was measured as stable end product, nitrite, according to the method of Miranda et al. ${ }^{29}$ The assay is based on the reduction of nitrate by vanadium trichloride combined with detection by the acidic Griess reaction. The diazotization of sulfanilic acid with nitrite at acidic $\mathrm{pH}$ and subsequent coupling with $\mathrm{N}-(10$ naphthyl)ethylenediamine produced an intensely colored product that is measured spectrophotometrically at $540 \mathrm{~nm}$. The levels of total NOx were expressed as mol $\mathrm{g}^{-1}$ wet tissue.

\section{Histopathology}

Histopathologic examination was performed on the animals of each group. Right kidney samples were taken. The tissue samples were fixed for at least 48 hours in 10\% formalin in phosphate buffer ( $\mathrm{pH}$ 7). The samples were then embedded in paraffin 
wax, cut into $5 \mu \mathrm{m}$ sections, and stained with hematoxylin and eosin. The slides were coded and were examined by a histopathologist who was unaware of the treated groups.

\section{Statistical analysis}

Data are expressed as mean \pm standard error. Statistical comparison between different groups was conducted using one-way analysis of variance (ANOVA) followed by a Tukey-Kramer multiple comparison test to judge the difference between various groups. Significance was accepted at $P<0.05$.

\section{Results}

\section{Effects of AG on $\mathrm{Hg}$-induced changes in serum biochemical parameters}

Serum creatinine and blood urea nitrogen (BUN) were significantly increased after injection of $\mathrm{Hg}$ as compared with the control group $(P<0.001)$ (Figures 1 and 2). Pretreatment of animals with $\mathrm{AG}(7.5 \mathrm{~g} / \mathrm{kg} /$ day per os $) 5$ days before and concomitantly with $\mathrm{Hg}$ significantly reduced the rise in the level of BUN and creatinine.

\section{Oxidative and nitrosative stress biomarkers}

Figures 3 and 4 show the effects of AG, Hg, and their combination on oxidative stress biomarkers in renal tissues, namely thiobarbituric acid reactive substance (TBARS) and reduced $\mathrm{GSH}$, respectively. $\mathrm{Hg}$ resulted in a significant decrease in GSH content to reach only $75 \%$ of control group. Also, it leads to a significant $73 \%$ increase in TBARS as compared to the control group. Combined AG treatment with $\mathrm{Hg}$ significantly decreased TBARS $(P<0.001)$ and restored GSH level in renal tissues compared to the control values. Figure 5 shows the effects of $\mathrm{AG}, \mathrm{Hg}$, and their combination on the level of NOx levels in rat renal tissues. Hg resulted in a significant $91 \%$ increase of NOx in renal tissues as compared to the control group. Combined AG treatment with $\mathrm{Hg}$ significantly decreased NOx in renal tissues $(P<0.05)$ compared to the control values.

\section{Antioxidant enzymes activities}

Figures 6 and 7 show the effects of AG, Hg, and their combination on the activity of antioxidant enzymes GSH-Px and catalase in renal tissues, respectively. $\mathrm{Hg}$ resulted in a significant decrease in both GSH-Px and catalase enzyme activities as compared to the control group $(P<0.001$ and $P<0.001$, respectively). Combined AG treatment with $\mathrm{Hg}$ significantly improved both enzymes' activity $(P<0.001)$ in renal tissues compared to the control values.

\section{Kidney pathology}

Pathological examination of the kidneys of control and AG groups showed normal morphology of the renal parenchyma

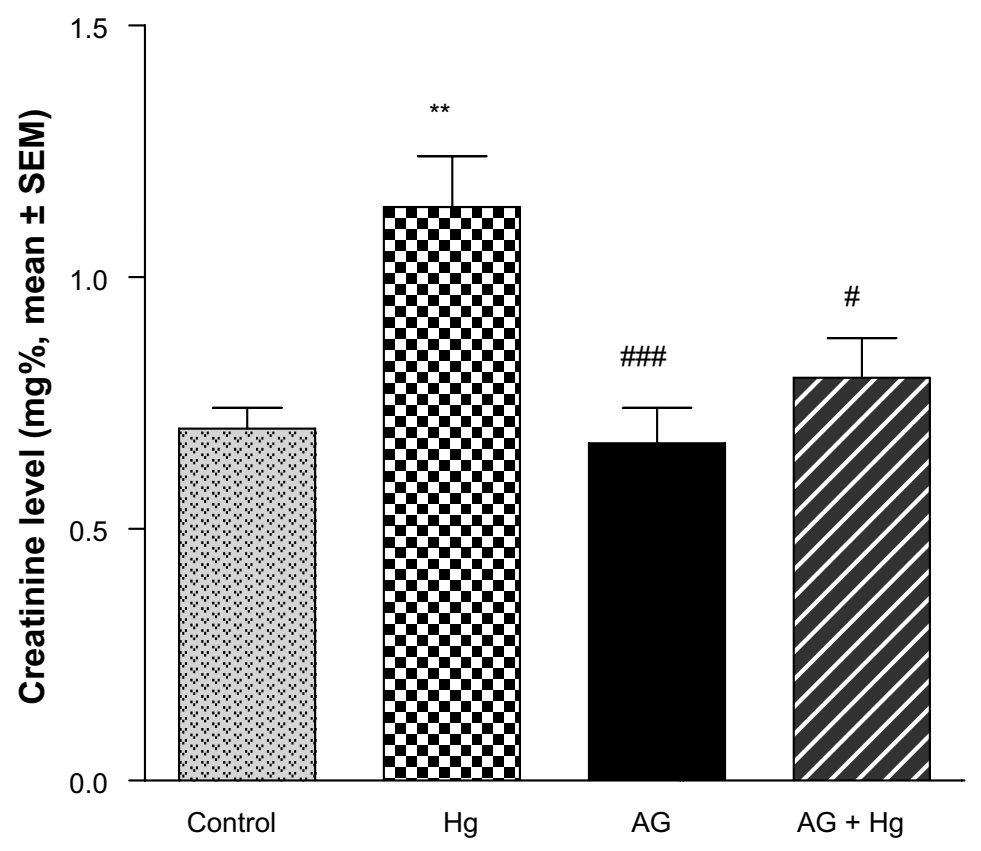

Figure I Effects of AG on elevated levels of serum creatinine induced by $\mathrm{Hg}$.

Notes: AG $(7.5 \mathrm{~g} / \mathrm{kg} /$ day $\mathrm{po})$ was given for 5 days before and concomitant with $\mathrm{Hg}$. Significantly different from control group, $* * P<0.0 \mathrm{I}$. Significantly different from $\mathrm{Hg}$, ${ }^{\# P}<0.05,{ }^{\#} \mathrm{P}<0.00 \mathrm{I}$.

Abbreviations: AG, Arabic gum; $\mathrm{Hg}$, mercury; SEM, standard error of the mean; po, per oral. 


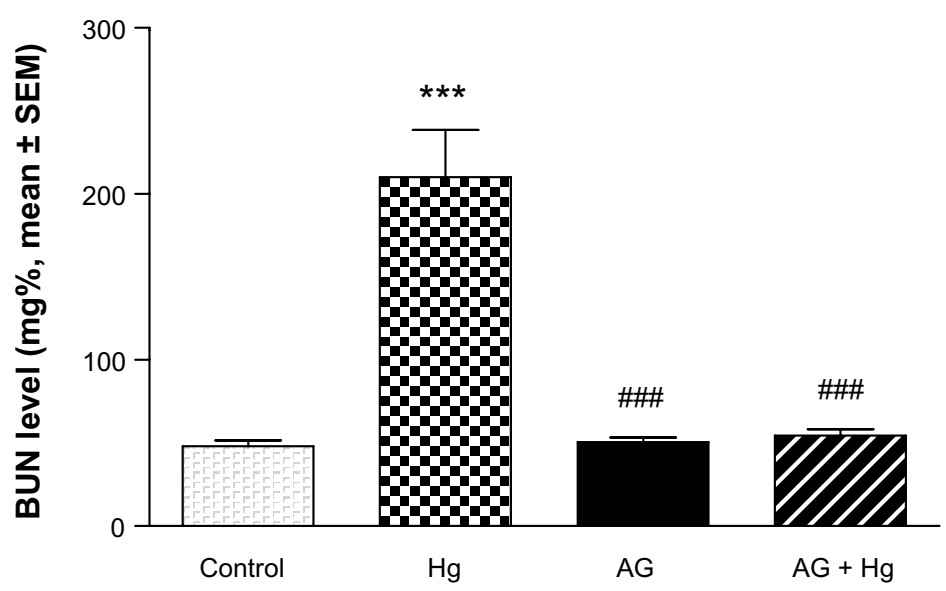

Figure 2 Effects of $A G$ on elevated levels of BUN induced by $\mathrm{Hg}$.

Notes: AG $(7.5 \mathrm{~g} / \mathrm{kg} / \mathrm{day} \mathrm{po})$ was given for 5 days before and concomitant with $\mathrm{Hg}$. Significantly different from control group, $* * * \mathrm{P}<0.00 \mathrm{I}$. Significantly different from $\mathrm{Hg}$, $\ldots$ P $<0.001$.

Abbreviations: AG, Arabic gum; BUN, blood urea nitrogen; $\mathrm{Hg}$, mercury; SEM, standard error of the mean; po, per oral.

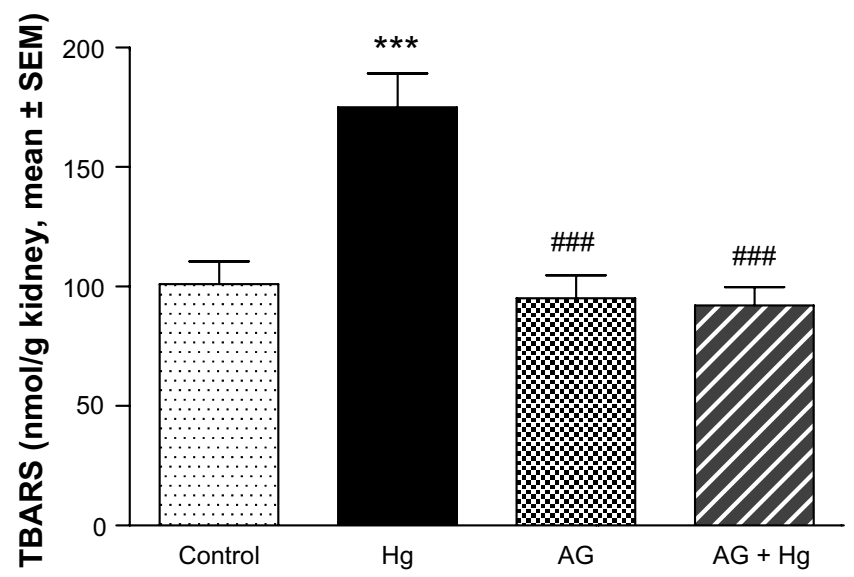

Figure 3 Effect of $\mathrm{Hg}, \mathrm{AG}$, and their combination on the levels of TBARS in rat renal tissues.

Notes: AG $(7.5 \mathrm{~g} / \mathrm{kg} /$ day po) was given for 5 days before and concomitant with $\mathrm{Hg}$. Significantly different from control group, $* * * P<0.00 \mathrm{I}$. Significantly different from $\mathrm{Hg}$, $\ldots+20.001$.

Abbreviations: AG, Arabic gum; Hg, mercury; SEM, standard error of the mean; TBARS, thiobarbituric acid reactive substances; po, per oral.

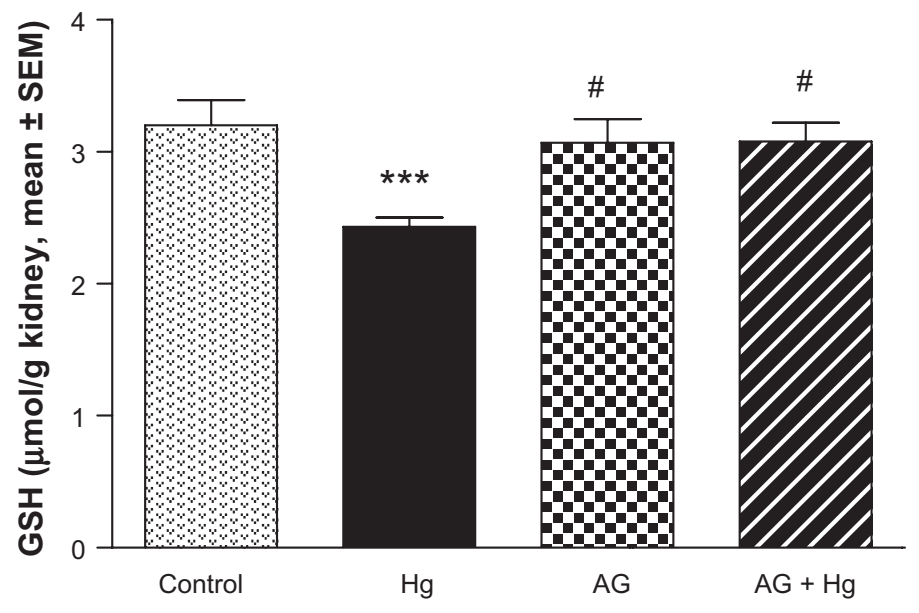

Figure 4 Effect of $\mathrm{Hg}, \mathrm{AG}$, and their combination on the levels of reduced $\mathrm{GSH}$ in rat renal tissues.

Notes: AG ( $7.5 \mathrm{~g} / \mathrm{kg} /$ day po) was given for 5 days before and concomitant with $\mathrm{Hg}$. Significantly different from control group, $* * * P<0.00 \mathrm{I}$. Significantly different from $\mathrm{Hg}$, ${ }^{\# P}<0.05$.

Abbreviations: AG, Arabic gum; GSH, glutathione; $\mathrm{Hg}$, mercury; SEM, standard error of the mean; po, per oral. 


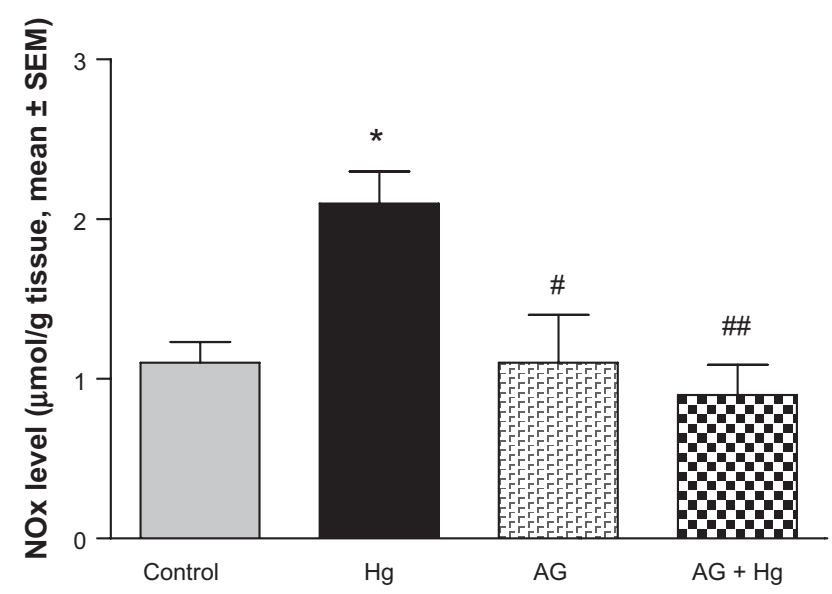

Figure 5 Effect of $\mathrm{Hg}$, AG, and their combination on total NOx levels in rat renal tissues.

Notes: AG $(7.5 \mathrm{~g} / \mathrm{kg} /$ day $\mathrm{po})$ was given for 5 days before and concomitant with $\mathrm{Hg}$. Significantly different from control group, $* P<0.05$. Significantly different from $\mathrm{Hg}$, ${ }^{\# P}<0.05,{ }^{\# P}<0.01$.

Abbreviations: AG, Arabic gum; Hg, mercury; NOx, nitrate/nitrite; SEM, standard error of the mean; po, per oral.

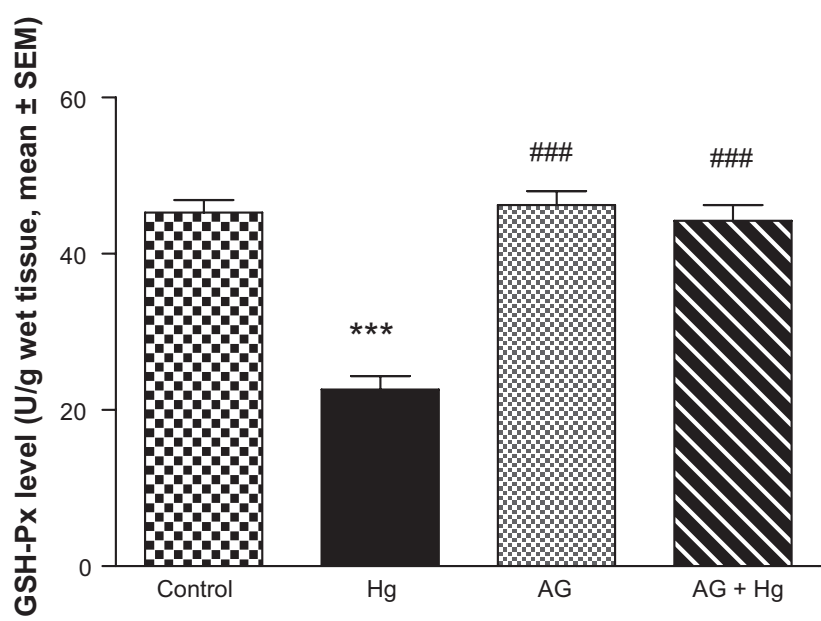

Figure 6 Effects of AG on changes in GSH-Px enzyme activities induced by $\mathrm{Hg}$.

Notes: AG $(7.5 \mathrm{~g} / \mathrm{kg} / \mathrm{day} \mathrm{po})$ was given for 5 days before and concomitant with $\mathrm{Hg}$. Significantly different from control group, $* * * P<0.00 \mathrm{I}$. Significantly different from $\mathrm{Hg}$, \# $<0.001$.

Abbreviations: AG, Arabic gum; GSH-Px, glutathione peroxidase; $\mathrm{Hg}$, mercury; SEM, standard error of the mean; po, per oral.

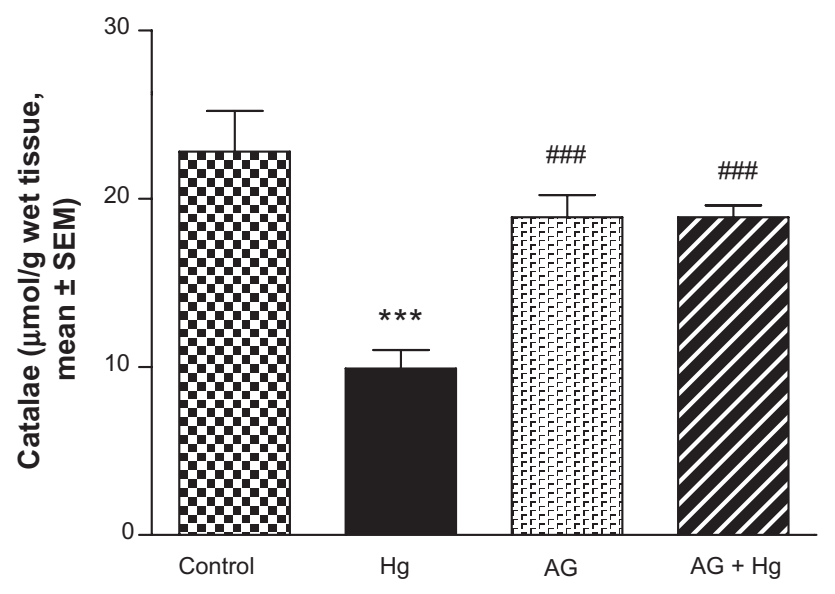

Figure $7 \mathrm{Effect}$ of $\mathrm{Hg}, \mathrm{AG}$, and their combination on the catalase activity in rat renal tissues.

Notes: AG $(7.5 \mathrm{~g} / \mathrm{kg} /$ day po) was given for 5 days before and concomitant with $\mathrm{Hg}$. Significantly different from control group, $* * * P<0.00 \mathrm{I}$. Significantly different from $\mathrm{Hg}$, \#\# $<$ 0.001.

Abbreviations: AG, Arabic gum; Hg, mercury; SEM, standard error of the mean; po, per oral. 
with well-defined glomeruli and tubules with non-significant changes (Figures 8 and 9). However, animals treated with $\mathrm{Hg}$ showed clear signs of glomerular and tubular necrosis, interstitial nephritis, and desquamation of the tubular epithelial cells in the renal cortex (Figure 10). Interestingly, kidney specimens from rats treated with $\mathrm{AG}$ and $\mathrm{Hg}$ revealed significant improvement in glomeruli and renal tubules, evidenced by less vacuolization and more preservation of tubular histology (Figure 11).

\section{Discussion}

Mercuric ion, one of strongest thiol-binding agents, increases the intracellular levels of ROS and induces oxidative stress, resulting in tissue damage. ${ }^{30-32} \mathrm{Hg}$ toxicity is associated with superoxide radical generation and GSH reduction. ${ }^{33,34}$ Our study demonstrates that the treatment of rats with $\mathrm{HgCl}_{2}$ revealed a significant enhancement in TBARS levels, indicative of the generation of lipid peroxides. Enhanced lipid peroxidation levels were also reported in $\mathrm{Hg}$ toxicity by Agarwal et al and Sener et al. ${ }^{13,35} \mathrm{HgCl}_{2}$ is known to increase the production of many ROS, such as superoxide and $\mathrm{H}_{2} \mathrm{O}_{2}$, which cause lipid peroxidation and subsequently oxidative tissue damage. ${ }^{36-38}$ Endogenous GSH has a specific role in protecting the body from $\mathrm{Hg}$ toxicity due to its function as a carrier of $\mathrm{Hg}$ and its antioxidant properties. GSH binds with $\mathrm{Hg}$ and forms a complex that prevents $\mathrm{Hg}$ from binding to cellular proteins and subsequently causing damage to both enzymes and tissue. ${ }^{39} \mathrm{Hg}$ poisoning leads to a reduction of intracellular GSH content and decreases the antioxidant potential of the cells. The present study revealed that Hg-treated rats showed a significant depletion of serum GSH levels. Agarwal et al reported a significant reduction of GSH levels in liver, kidney and brain tissues. ${ }^{12,13}$

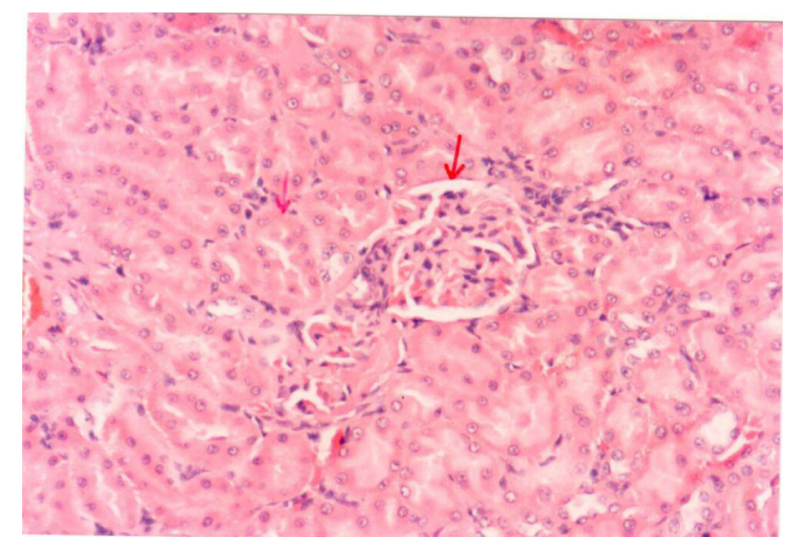

Figure 8 A photomicrograph of the renal cortex of a control rat. The red arrows showing parenchyma with normal glomeruli and tubules, $\times 200$ magnification.

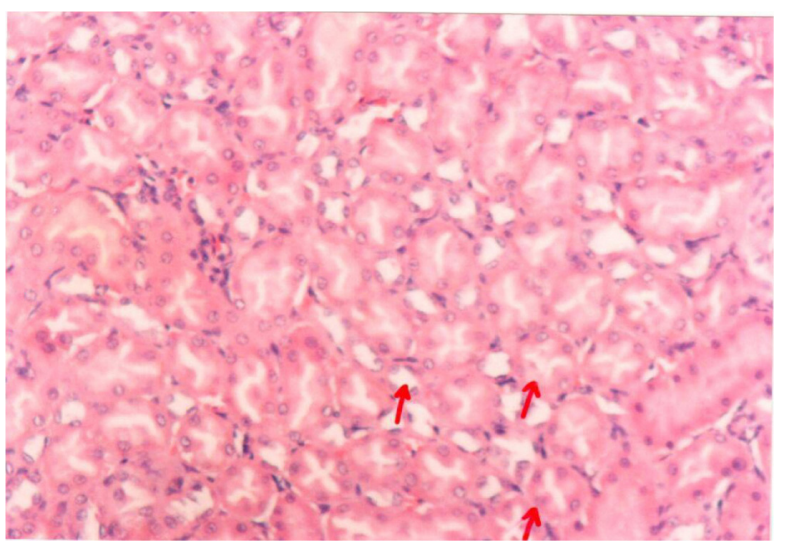

Figure 9 A photomicrograph of kidney of an Arabic gum-treated rat. The red arrows showing cortical tubules and peritubular capillaries with no pathogenic changes, $\times 200$ magnification.

Alterations observed in the activity of GSH-Px and catalase in kidney tissues of $\mathrm{Hg}$-exposed animals indicate the generation of $\mathrm{ROS}\left(\mathrm{O}_{-2}\right.$ or $\left.\mathrm{H}_{2} \mathrm{O}_{2}\right)$. Inhibition in the activity of renal antioxidant enzymes, such as superoxide dismutase (SOD), GSH-Px, and catalase, in addition to depletion of GSH levels was also reported earlier. ${ }^{40,41}$ Enhanced creatinine and BUN levels indicate nephrotoxicity, as reported by Rumbeiha et al. ${ }^{42}$ Histopathologic alterations in kidney tissues after $\mathrm{Hg}$ exposure were revealed. Rumbeiha et al, Al-Saleh et al, Sarwar Alam et al, and Augusti et al have also reported similar histopathologic alterations in $\mathrm{Hg}$-induced nephrotoxicity. ${ }^{42-45}$

Pretreatment with AG attenuated the Hg-induced oxidative damage. Hence, pretreatment with AG significantly restored the increased TBARS and decreased GSH levels to the normal values. This could be attributed to the excellent antioxidant properties of AG. ${ }^{46}$ These properties seems to

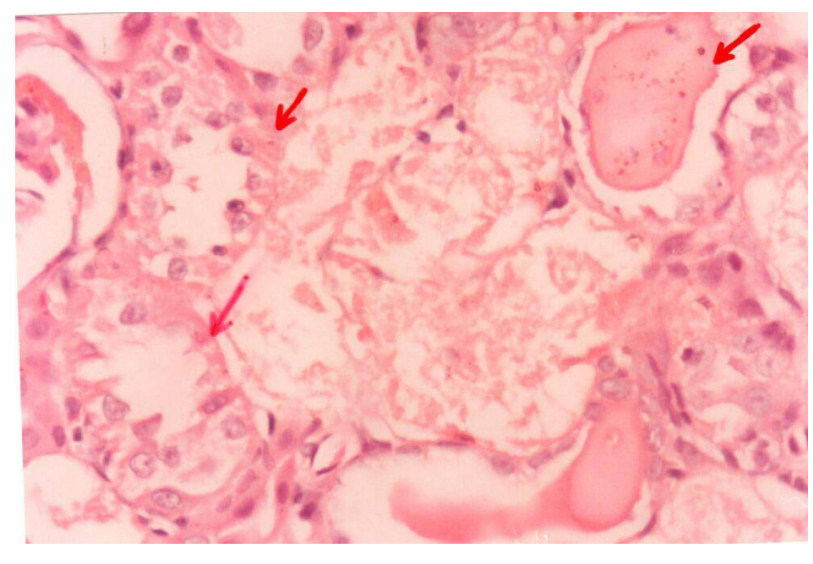

Figure $10 \mathrm{~A}$ photomicrograph of the kidney of an mercury-treated rat. The red arrows showing necrotic changes of the rental tubular cells and some tubles contain casts, $\times 400$ magnification. 


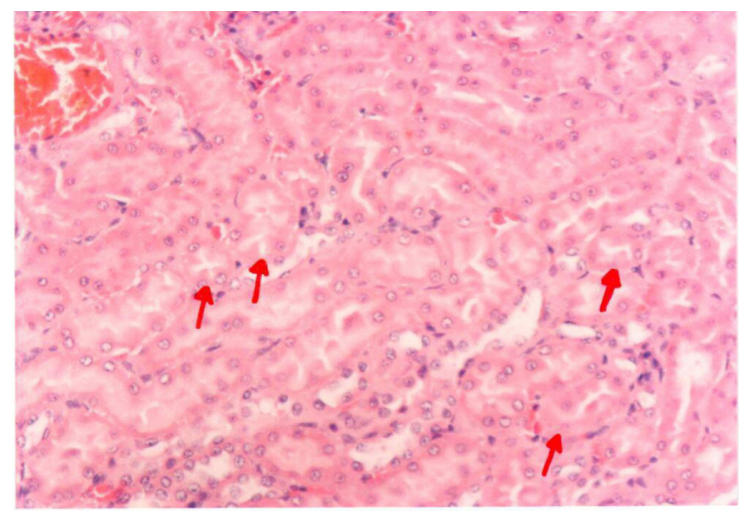

Figure I I A photomicrograph of the kidney of an Arabic gum- and mercury-treated rat. The red arrows showing insignificant tubular epithelial changes in the form of cloudy swelling, $\times 200$ magnification.

be due to its ability to scavenge free radicals. The kidneys are the primary target organ for accumulation and toxicity of inorganic $\mathrm{Hg}^{5}$ In fact, in as little as 1 hour, $50 \%$ of an administered dose of inorganic $\mathrm{Hg}$ is present in the kidney. ${ }^{47}$ Within the kidney, the majority of mercuric ions were detected in the cortex and outer stripe of the outer medulla. This finding was expected considering that the proximal tubule, which spans these two renal zones, is the primary site of accumulation of mercuric ions. ${ }^{5}$ The histopathologic findings in the kidney tissue of $\mathrm{Hg}$-treated rats include severe diffuse acute necrosis of the tubular epithelium, fragmentation and shedding of tubular epithelium in the lumina of the renal tubules, and interstitial edema as a result of tubular leakage. The interaction of $\mathrm{Hg}$ with protein thiol groups is thought to play an important role in nephrotoxicity induced by $\mathrm{Hg}$ at the cellular level. ${ }^{5}$ The results of this study indicate that $\mathrm{AG}$ improved $\mathrm{Hg}$-induced nephrotoxicity, manifested by a decrease in both serum creatinine and urea levels, and minimized the intensity of the renal lesions. The nephroprotective effect of AG against many nephrotoxic agents was noted in several reports. ${ }^{18,21}$ 48-53 The antioxidation induced by AG might be one of the most likely mechanisms contributing to its beneficial effect against renal injury. This antioxidant effect of AG was confirmed previously by in vitro studies, which showed that AG had a dose-dependent scavenging of superoxide radicals generated enzymatically and nonenzymatically. ${ }^{54}$ It could be suggested that $\mathrm{AG}$ scavenges $\mathrm{Hg}$ free-radical generation and, in turn, inhibits lipid peroxidation-induced injury in renal tissues, which has been suggested to protect renal structure and function. Therefore, the protective effect is provided by $\mathrm{AG}$ on renal tissue through antioxidants as well as by scavenging free radicals in vivo.

\section{Conclusion}

In summary, our data indicate that $\mathrm{Hg}$-induced nephrotoxicity is related to lipid peroxidation. Coadministration of $A G$ provided protection against HG-induced nephrotoxicity, possibly by inhibiting the free radical mediated process. These protective effects of AG on renal injury induced by $\mathrm{Hg}$ might have a considerable impact on developing clinically feasible strategies to treat patients with toxin-induced renal failure.

\section{Disclosure}

The authors report no conflicts of interest in this work.

\section{References}

1. Mahboob M, Shireen KF, Atkinson A, Khan AT. Lipid peroxidation and antioxidant enzyme activity in different organs of mice exposed to low level of mercury. J Environ Sci Health B. 2001;36(5):687-697.

2. Sener G, Sehirli AO, Avanoglu-Dülger G. Melatonin protects against mercury (11)-induced oxidative tissue damage in rats. Pharmacol Toxicol. 2003;93(6):290-296.

3. Emanuelli T, Rocha JB, Pereira ME, et al. Effect of mercuric chloride intoxication and dimercaprol treatment on delta-aminolevulinate dehydratase from brain, liver and kidney of adult mice. Pharmacol Toxicol. 1996;79(3):136-143.

4. Tanaka-Kagawa T, Suzuki M, Naganuma A, Yamanaka N, Imura N. Strain difference in sensitivity of mice to renal toxicity of inorganic mercury. J Pharmacol Exp Ther. 1998;285(1):335-341.

5. Zalups RK. Molecular interactions with mercury in the kidney. Pharmacol Rev. 2000;52(1):113-143.

6. Nogueira CW, Soares FA, Nascimento PC, Muller D, Rocha JB 2,3-Dimercaptopropane-1-sulfonic acid and meso-2,3-dimercaptosuccinic acid increase mercury- and cadmium-induced inhibition of deltaaminolevulinate dehydratase. Toxicology. 2003;184(2-3):85-95.

7. Li Z, Wu J, Deleo CJ. RNA damage and surveillance under oxidative stress. IUBMB Life. 2006;58(10):581-588.

8. Clarkson TW. The toxicology of mercury. Crit Rev Clin Lab Sci. 1997;34(4):369-403.

9. Patrick L. Mercury toxicity and antioxidants. Part 1: Role of glutathione and alpha-lipoic acid in the treatment of mercury toxicity. Altern Med Rev. 2002;7(6):456-471.

10. Pillai A, Gupta S. Antioxidant enzyme activity and lipid peroxidation in liver of female rats co-exposed to lead and cadmium: effects of vitamin E and Mn2+. Free Radic Res. 2005;39(7):707-712.

11. Nava M, Romero F, Quiroz Y, Parra G, Bonet L, Rodríguez-Iturbe B. Melatonin attenuates acute renal failure and oxidative stress induced by mercuric chloride in rats. Am J Physiol Renal Physiol. 2000;279(5): F910-F918.

12. Agarwal R, Goel SK, Behari JR. Detoxification and antioxidant effects of curcumin in rats experimentally exposed to mercury. J Appl Toxicol. 2010;30(5):457-468.

13. Agarwal R, Goel SK, Chandra R, Behari JR. Role of vitamin E in preventing acute mercury toxicity in rat. Environ Toxicol Pharmacol. 2010;29(1):70-78.

14. Ahn CB, Song CH, Kim WH, Kim YK. Effects of Juglans sinensis Dode extract and antioxidant on mercury chloride-induced acute renal failure in rabbits. $J$ Ethnopharmacol. 2002;82(1):45-49.

15. Oda SS, El-Ashmawy IM. Adverse effects of the anabolic steroid, boldenone undecylenate, on reproductive functions of male rabbits. Int J Exp Pathol. 2012;93(3):172-178.

16. Sarwar Alam M, Kaur G, Jabbar Z, Javed K, Athar M. Eruca sativa seeds possess antioxidant activity and exert a protective effect on mercuric chloride induced renal toxicity. Food Chem Toxicol. 2007;45(6):910-920. 
17. Rehan A, Johnson KJ, Kunkel RG, Wiggins RC. Role of oxygen radicals in phorbol myristate acetate-induced glomerular injury. Kidney Int. 1985;27(3):503-511.

18. Al-Majed AA, Mostafa AM, Al-Rikabi AC, Al-Shabanah OA. Protective effects of oral Arabic gum administration on gentamicininduced nephrotoxicity in rats. Pharmacol Res. 2002;46(5):445-451.

19. Ramsammy L, Ling KY, Josepovitz C, Levine R, Kaloyanides GJ. Effect of gentamicin on lipid peroxidation in rat renal cortex. Biochem Pharmacol. 1985;34(21):3895-3900.

20. Salahudeen AK, Clark EC, Nath KA. Hydrogen peroxide-induced renal injury. A protective role for pyruvate in vitro and in vivo. J Clin Invest. 1991;88(6):1886-1893.

21. Al-Majed AA, Abd-Allah AR, Al-Rikabi AC, Al-Shabanah OA, Mostafa AM. Effect of oral administration of Arabic gum on cisplatininduced nephrotoxicity in rats. J Biochem Mol Toxicol. 2003;17(3): 146-153.

22. Augusti PR, Conterato GM, Somacal S, et al. Effect of lycopene on nephrotoxicity induced by mercuric chloride in rats. Basic Clin Pharmacol Toxicol. 2007;100(6):398-402.

23. Bonsnes RW, Taussky HN. On the colorimetric determination of creatinine by the Jaffe reaction. J Biol Chem. 1945;158:581-591.

24. Hallett CJ, Cook JG. Reduced nicotinamide adenine dinucleotidecoupled reaction for emergency blood urea estimation. Clin Chim Acta. 1971;35(1):33-37

25. Ellman GL. Tissue sulfahydryl groups. Arch Biochem Biophys. 1959; 82(1):70-77.

26. Ohkawa H, Ohish N, Yagi K. Assay for lipid peroxides in animal tissues by thiobarbituric acid. Anal Biochem. 1979;95(2):351-358.

27. Kraus RJ, Ganther HE. Reaction of cyanide with glutathione peroxidase. Biochem Biophys Res Commun. 1980;96(3):1116-1122.

28. Higgins CP, Baehner RL, McCallister J, Boxer LA. Polymorphonuclear leukocyte species differences in the disposal of hydrogen peroxide (H2O2). Proc Soc Exp Biol Med. 1978;158(3):478-481.

29. Miranda KM, Espey MG, Wink DA. A rapid, simple spectrophotometric method for simultaneous detection of nitrate and nitrite. Nitric Oxide. 2001;5(1):62-71.

30. Zahir F, Rizwi SJ, Haq SK, Khan RH. Low dose mercury toxicity and human health. Environ Toxicol Pharmacol. 2005;20(2):351-360.

31. Hussain S, Atkinson A, Thompson SJ, Khan AT. Accumulation of mercury and its effect on antioxidant enzymes in brain, liver, and kidneys of mice. J Environ Sci Health B. 1999;34(4):645-660.

32. Reus IS, Bando I, Andrés D, Cascales M. Relationship between expression of HSP70 and metallothionein and oxidative stress during mercury chloride induced acute liver injury in rats. $J$ Biochem $\mathrm{Mol}$ Toxicol. 2003;17(3):161-168.

33. Girardi G, Elías MM. Mercuric chloride effects on rat renal redox enzymes activities: SOD protection. Free Radic Biol Med. 1995;18(1):61-66.

34. Miura K, Naganuma A, Himeno S, Imura N. Mercury toxicity. In: Goyer RA, Cherian MG, editors. Toxicology of Metals: Biochemical Aspects. Berlin: Springer-Verlag; 1995:163-187.

35. Sener G, Sehirli O, Tozan A, Velioğlu-Ovunç A, Gedik N, Omurtag GZ. Ginkgo biloba extract protects against mercury(II)-induced oxidative tissue damage in rats. Food Chem Toxicol. 2007;45(4):543-550.

36. Miller DM, Lund BO, Woods JS. Reactivity of $\mathrm{Hg}(\mathrm{II})$ with superoxide: evidence for the catalytic dismutation of superoxide by $\mathrm{Hg}$ (II). J Biochem Toxicol. 1991;6(4):293-298.

Drug Design, Development and Therapy

\section{Publish your work in this journal}

Drug Design, Development and Therapy is an international, peerreviewed open-access journal that spans the spectrum of drug design and development through to clinical applications. Clinical outcomes, patient safety, and programs for the development and effective, safe, and sustained use of medicines are a feature of the journal, which
37. Huang YL, Cheng SL, Lin TH. Lipid peroxidation in rats administrated with mercuric chloride. Biol Trace Elem Res. 1996;52(2):193-206.

38. Linden A, Gülden M, Martin HJ, Maser E, Seibert H. Peroxide-induced cell death and lipid peroxidation in C6 glioma cells. Toxicol In Vitro. 2008;22(5):1371-1376.

39. Kromidas L, Trombetta LD, Jamall IS. The protective effects of glutathione against methylmercury cytotoxicity. Toxicol Lett. 1990;51(1):67-80.

40. Agarwal R, Raisuddin S, Tewari S, Goel SK, Raizada RB, Behari JR. Evaluation of comparative effect of pre- and posttreatment of selenium on mercury-induced oxidative stress, histological alterations, and metallothionein mRNA expression in rats. $J$ Biochem Mol Toxicol. 2010;24(2):123-135.

41. Gstraunthaler G, Pfaller W, Kotanko P. Glutathione depletion and in vitro lipid peroxidation in mercury or maleate induced acute renal failure. Biochem Pharmacol. 1983;32(19):2969-2972.

42. Rumbeiha WK, Fitzgerald SD, Braselton WE, Roth RA, Kaneene JB. Potentiation of mercury-induced nephrotoxicity by endotoxin in the Sprague-Dawley rat. Toxicology. 2000;149(2-3):75-87.

43. Al-Saleh I, El-Doush I, Shinwari N, Al-Baradei R, Khogali F,Al-Amodi M. Does low mercury containing skin-lightening cream (fair and lovely) affect the kidney, liver, and brain of female mice? Cutan Ocul Toxicol. 2005;24(1):11-29.

44. Sarwar Alam M, Kaur G, Jabbar Z, Javed K, Athar M. Eruca sativa seeds possess antioxidant activity and exert a protective effect on mercuric chloride induced renal toxicity. Food Chem Toxicol. 2007;45(6):910-920.

45. Augusti PR, Conterato GM, Somacal S, et al. Effect of lycopene on nephrotoxicity induced by mercuric chloride in rats. Basic Clin Pharmacol Toxicol. 2007;100(6):398-402.

46. Ali BH. Does gum Arabic have an antioxidant action in rat kidney? Ren Fail. 2004;26(1):1-3.

47. Zalups RK. Early aspects of the intrarenal distribution of mercury after the intravenous administration of mercuric chloride. Toxicology. $1993 ; 79(3): 215-228$.

48. Mahmoud MF, Diaai AA, Ahmed F. Evaluation of the efficacy of ginger, Arabic gum, and Boswellia in acute and chronic renal failure. Ren Fail. 2012;34(1):73-82.

49. Ali BH, Al-Husseni I, Beegam S, et al. Effect of gum Arabic on oxidative stress and inflammation in adenine-induced chronic renal failure in rats. PLoS ONE. 2013;8(2):e55242.

50. Ali BH, Ziada A, Al Husseni I, Beegam S, Al-Ruqaishi B, Nemmar A. Effect of Acacia gum on blood pressure in rats with adenine-induced chronic renal failure. Phytomedicine. 2011;18(13):1176-1180.

51. Ali BH, Al-Salam S, Al Husseni I, et al. Effects of Gum Arabic in rats with adenine-induced chronic renal failure. Exp Biol Med (Maywood). 2010;235(3):373-382.

52. Ali AA, Ali KE, Fadlalla AE, Khalid KE. The effects of gum Arabic oral treatment on the metabolic profile of chronic renal failure patients under regular haemodialysis in Central Sudan. Nat Prod Res. 2008;22(1): $12-21$.

53. Nasir O, Umbach AT, Rexhepaj R, et al. Effects of gum Arabic (Acacia senegal) on renal function in diabetic mice. Kidney Blood Press Res. 2012;35(5):365-372.

54. Abd-Allah AR, Al-Majed AA, Mostafa AM, Al-Shabanah OA, Din AG, Nagi MN. Protective effect of Arabic gum against cardiotoxicity induced by doxorubicin in mice: a possible mechanism of protection. J Biochem Mol Toxicol. 2002;16(5):254-259.

\section{Dovepress}

has also been accepted for indexing on PubMed Central. The manuscript management system is completely online and includes a very quick and fair peer-review system, which is all easy to use. Visit http://www.dovepress.com/testimonials.php to read real quotes from published authors.

Submit your manuscript here: http://www.dovepress.com/drug-design-development-and-therapy-journal 